\title{
A Coevolutionary Model of Environmental Consciousness Development among School Children on the Basis of Sustainability Concepts
}

\author{
Natalya Fedorovna Vinokurova
}

Minin Nizhny Novgorod State Pedagogical University, Russia, 603950, Nizhny Novgorod, Ulyanov Street, 1

Vera Viktorovna Nikolina

Nizhny Novgorod Institute of the Education Development, Russia,603122, Nizhny Novgorod, Vaneeva Street, 203

Irina Aleksandrovna Shevchenko

Minin Nizhny Novgorod State Pedagogical University, Russia, 603950, Nizhny Novgorod, Ulyanov Street, 1

Olga Evgenyevna Efimova

Minin Nizhny Novgorod State Pedagogical University, Russia, 603950, Nizhny Novgorod, Ulyanov Street, 1

Doi:10.5901/mjss.2015.v6n6s2p315

Abstract

The article represents the author's model of environmental consciousness development among school children. The model includes theoretical and methodological basis and pedagogical system which correspond to sustainable (balanced) development concepts. The pedagogical model of environmental consciousness development among school children is accompanied by programs, school books and methodological guides, work books published by central and regional publishing houses of Russia. The environmental consciousness development model has been tested for more than 10 years in Nizhny Novgorod region - one of the largest regions of Russia. The model's implementation allows to significantly increase environmental consciousness, to help understand significance of environment, to develop environmental attitudes and mentality and environmentally oriented activities aimed at sustainable (balanced) development.

Keywords: Environmental (ecological) culture, sustainable (balanced) development, education in the domain of sustainable development, model of environmental consciousness development among school children.

\section{Introduction}

\subsection{Problem definition}

Current critical environmental situation in the world and in many regions of Russia underlines the importance of the problem of environmental education of the younger generation. Environmental education of the XXI century shall be focused on future development, and encourage the development of environmental consciousness as the key factor of upcoming changes aimed at sustainability achievement (Doronina, Kuznetsov and Rokhianin, 2005).

The issue of the core defining role of culture in the process of transition to sustainable development was considered at the international conference in Rio de Janeiro in 2012 (Rio+20). In the course of the conference it was stated that in order to achieve sustainability it is necessary to have a target-oriented development of environmental consciousness (World bank, 2014).

1.2 Meanwhile the society is dominated by the consumer attitude towards nature, the conception of humankind as nature's conqueror, social apathy in regard to resolution of environmental problems. General low cultural level which provokes irresponsible, utilitarian approach to environment.

In order to overcome the existing discrepancy between the world community demands and current reality it is necessary to develop environmental consciousness of the population in accordance with a new co-evolutionary system of values based on the concept of the unity of man and nature, their harmonious relationships for the purpose of sustainable development, and reduction of excessive use of natural resources by the humankind (transition from hyper-consumption 
to the concept of sufficiency).

The core solution of this problem lies within the school education which is intended to further drive sustainable development. Solution of this problem is connected to the creation of a co-evolutionary model of environmental consciousness development among school children. This issue represents the goal of the present research. In order to identify theoretical and methodological basis and practical methods it is important to discuss the issue of continuity in the process of environmental consciousness development and specific character of approaches and principles used as strategic reference points.

1.3 In the course of our research we have analyzed approaches and milestones of Russian and foreign scientists connected to traditions and innovations in the domain of environmental education and consciousness development (Gluzdova, Vinokurova and Nikolina, 2002). We have distinguished environment-oriented, anthropocentric, coevolutionary stages of environmental education development. Each stage was characterized by different approaches and mechanisms of environmental consciousness development among school children.

At the first - environment-oriented stage (60's of the XX century) environmental culture development among schoolchildren was connected to environmental protection activities of school children (Zverev, 1980).

At the second - anthropocentric stage (80-90's of the XX century) environmental culture development was performed in the context of conservation of resources and health. Within this model the importance was attributed to the link of environmental culture development with such environmentally-oriented personal qualities as responsible attitude to environment, readiness to perform environmental activities (Suravegina, 1986). This stage reveals the sense of a crossdisciplinary content of environmental education which ensures the development of individual environmental culture.

The crisis of the environmental education development which occurred at the second stage was due to the discrepancy between the goal of the environmental education - development of environmental consciousness which implies comprehensive development of all spheres of individual consciousness and engagement of school children into cognitive, communicative, practice-oriented and other types of activities and domination of the cognitive aspect of environmental education.

Starting from the middle of 90's of the XX century scientists and teachers have noticed a slowdown in the development of environmental education. It can be mainly explained by the fact that as a result of "environmental boom" a "critical mass" of divergent efforts has been accumulated.

At present specialists consider that a further development of environmental education among children shall be linked to the idea of sustainable development which implies creation of a new model of environmental culture. New coevolutionary stage (from the beginning of the XXI century) unites the above stages in the form of partnership, inherent worth of man and nature and necessity of their connected interdependent change for the purpose of sustainable development. This stage requires scientific and pedagogical research in the domain of creation of a new co-evolutionary model of environmental culture development.

Design of a co-evolutionary model of environmental culture development was performed on the basis of the following researches:

- philosophic researches about cultural and civilization ideas of ecological development (V.I. Vernadksy, P. Teilhard de Chardin, N.N. Moiseev, A.D. Ursul, N.M. Mamedov, A. Peccei, D. Meadows, T. Miller);

- psychological and pedagogical researches in the domain of environmental culture development and development of ecological values making part of such culture (S.V. Alekseev, S.N. Glazachev, S.D. Deryabo, D.S. Ermakov, A.N. Zakhlevny, I.D. Zverev, V.I. Panov, G.S. Kamerilova, D.S. Likhachev, I.N. Ponomareva, T.I. Suravegina, V.A. Yasvin).

1.4 The present research was developed on the basis of a number of hypothesis provisions: a model of environmental culture development among school children will be consistent with current cultural and civilization ideas of ecological development (co-evolution, sustainability, noosphere), if:

- theoretical and methodological basis is presented in the form of a block of axiological, culturological, personal and pragmatist, co-evolutionary, system and structural approaches and principles reflecting the comprehensive influence on all spheres of individual consciousness;

- model structure includes interdependent target-oriented, substantive, procedural, performance evaluation components;

- methodological materials accompanying the process of ecological culture development reflect new values of ecological development. 


\section{Methodology}

2.1 Methodological basis of environmental culture development model construction is represented by the developed concept of ecological education of school children of the city of Nizhny Novgorod on the basis of sustainable development ideas (Gluzdova, Vinokurova and Nikolina, 2002). We have created a co-evolutionary model of ecological culture development among school children at three levels: philosophical and methodological, theoretical and methodological and pedagogical (Fig. 1)

Table 1. Co-evolutionary model of environmental consciousness development among school children

\begin{tabular}{|c|c|c|c|}
\hline \multicolumn{4}{|l|}{ Philosophical and methodological level } \\
\hline \multicolumn{4}{|c|}{$\begin{array}{l}\text { Ecological development ideas: noosphere, coevolution, sustainable development, ecological culture - as key factors of future } \\
\text { changes aimed at sustainability. }\end{array}$} \\
\hline \multicolumn{4}{|l|}{ Theoretical and methodological level } \\
\hline \multicolumn{2}{|c|}{$\begin{array}{l}\text { Approaches: axiological, culturological, personal and } \\
\text { pragmatist, co-evolutionary, system and structural. }\end{array}$} & \multicolumn{2}{|c|}{$\begin{array}{l}\text { Principles: cultural and artistic, integral conceptual, consolidation and } \\
\text { communication, orientation at actually significant environmental } \\
\text { problems, unique character of a location, global unity. }\end{array}$} \\
\hline \multicolumn{4}{|l|}{ Pedagogical level } \\
\hline $\begin{array}{l}\text { Target-oriented component } \\
\text { Environmental culture - strategic } \\
\text { target of environmental education for } \\
\text { the purpose of sustainability. }\end{array}$ & $\begin{array}{l}\text { Substantive } \\
\text { component } \\
\text { - cognitive } \\
\text { - axiological, } \\
\text { - regulatory, } \\
\text { - artistic and } \\
\text { pragmatic, } \\
\text { - behavioral. }\end{array}$ & $\begin{array}{l}\text { Procedural component } \\
\text { - culture and adaptation, } \\
\text { - culture and conception, } \\
\text { - culture and creation. }\end{array}$ & $\begin{array}{l}\text { Performance evaluation component } \\
\text { Levels of development (high, medium, } \\
\text { low) }\end{array}$ \\
\hline
\end{tabular}

Philosophical and methodological level is based on the ideas of ecological development: noosphere, coevolution, sustainable development, environmental consciousness as the key factor of transition to a sustainable development model.

The idea of noosphere was proposed by V.I. Vernadsky. According to this idea the humanity is inevitably transitioning due to a joint thoughtful activity towards the noosphere, where a human reason will play the predominant role in the harmonization of relationships within the "man-nature" system. The idea of noosphere orients the modern science and education to a transition from the model of consumption and destruction towards the model of creation and rehabilitation. The idea of coevolution proposed by the academician N.N. Moiseev presupposes that the ideology of nature's subjugation will be overcome, in accordance with this idea relationships between mankind and nature shall be based upon empathy, co-existence, partnership, harmonious co-development. The idea of sustainable development has been voiced for the first time by the UN Commission on Environment and Development in the international report "Our Common Future" (1989). The idea of sustainable development implies a balance between economic, environmental and social development. Education within this context gets a top-priority role in the development of environmental consciousness. Efficient implementation of this role is connected with the orientation of the educational targets towards the development among pupils of environmental culture with the core element of it being the idea of environmental development.

Theoretical and methodological foundation of environmental consciousness development among children is made of: axiological, culturological, system and structural, personal and pragmatic, co-evolutionary approaches and corresponding principles.

Axiological approach is a backbone factor of design activities for the purpose of creation of the environmental consciousness development model for school children. It provides concepts of axiological reference points of the environmental education. Implementation of this approach allows to reveal environmental values and their functions in the development of culture of man-to-nature relationships. Axiological approach ensures a harmonization of perception and spiritual and ethical development of man and nature, it determines new individual attitudes to nature which is now considered to be intrinsically valuable with a man being a part of nature. While characterizing the environmental values we would like to state that they set axiological means of interaction of man with nature on the basis of sustainability ideas. Apart from regulatory function ecological values also perform anticipative and conceptual functions in the development of man-to-nature relationships culture, in the human society they act as strategic goals which encourage people to take part 
in joint environmentally-oriented constructive efforts. Ecological values act as a link between environmental culture of human society and individual environmental culture. At the current stage within the context of sustainable development ideas ecological values form the basis of social consensus foundation of cultural identification of individuals and society, necessary component of environmental security, criterion of viability and sustainability of a society as a system while fixing an axiological homogeneity in it. In the conditions of the establishment of a post-industrial society which is characterized by uncertainty, crises, dynamism, multidimensional coexistence of various cultures, ecological values serve as a reference point and direct the development of environmental culture to welfare, responsibility, conservation of nature, safe healthy environment, future prospects, which constitute the axiological basis of sustainable development ideas.

Culturological approach to the solution of the problem of environmental culture development among school children demonstrates this culture as a qualitative state of the general culture. Historically a new stage in the development of culture in the conditions of ecological crisis allows to determine an environmental culture as a type of spiritual culture. Culturological approach in this context steers the man-to-nature interaction to dialogue as opposed to the ideology of contest, conquest, exploitation. Culturological approach stimulates the creation of the model of environmental consciousness development within the context of the ideas which represent individuals as creators, actors capable of cultural development. From the point of view of culturological approach the education focuses on the culture actor who creates culture and who is capable of cultural development and self-limitation. The cultural approach is aimed at overcoming, alienation of school children from studied substance, "growth" of individual senses of environmental culture by means of engaging school children in the study of actual natural objects, cultural events, art works which reveal harmonious relationships between man and nature. In the course of the research it was established that the culturological approach is implemented by means of ecocultural identification, i.e. establishment of a spiritual unity with ecological traditions of the world and the native land, creative activities aimed at harmonizing the relationships between man and nature, conservation of cultural and natural heritage.

Personal and pragmatic approach implies the introduction of the idea of an individual as an actor in the model. This approach orients the model to the ideas of humanism, responsible activities, aimed at implementation of a sustainability ideology.

Personal and pragmatic approach manifests itself by means of taking into consideration a subjective experience of school children in the domain of study and resolution of environmental problems of various scales. It is oriented to the implementation of mechanisms of self-education, self-fulfillment when solving scholastic and real ecological problems on the basis of creative activities in a local region.

Co-evolutionary approach orients the model to co-evolutionary system of values which reflect the harmony and cocreation of man and nature. It implies significant change of values aimed at:

- perception of a man as a specific ecological phenomenon integrated in the natural system;

- man-to-nature interaction based on partnership, tolerance, system of compromises for the purpose of sustainability;

- performance by a man of managerial and criteria-setting functions for the purpose of sustainability;

- predominance of ecological over economical, expressed in the form of ethical and ecological imperative principle;

- inherent worth of man and nature as equal actors of relationships.

This particularities form the basis for the establishment of a new world picture and vision oriented at the harmonious relationships of man and nature. Co-evolution within this context represents the process of development over time, harmonious coexistence of man and nature. Consequently, it means that drastic changes of beliefs and principles shall be implemented in the course of ecological culture development.

Theoretical and methodological foundation for the construction of co-evolutionary model of environmental culture development among school children includes a number of principles which reflect a comprehensive influence on all spheres of individual consciousness.

Cultural and artistic principle is one of the leading ones used for the model construction and it reflects the development of mental creativity in the course of resolution of environmental problems in accordance with the requirements of cultural and nature-aligned activities. Cultural and artistic principle in the resolution of the problem of environmental consciousness development considers such consciousness as a part of a general culture, historical new stage of its development which allows to consider an ecological culture as a type of spiritual culture. This principle changes the perception of main goals of education as strictly informational and knowledge-providing, it eliminates strictly scientific focus of education substance and principles of education plan development, it expands cultural foundations and substance of education and upbringing, introduces the categories of productivity and creativity in the activities of school 
children (Vinokurova, Kamerilova, Nikolina et al., 2008).

Axiological principle plays a major role in the development of ecological culture of an individual in the XXI century, since ecological values perform the above functions in the relationships of man and nature. This principle ensures orientation of ecological education towards harmonization of scientific cognition and spiritual and ethical development. It determines a new individual axiological perception of nature as an inherent worth, of a man being a part of nature, it implements the ideals of ecohumanism, ecological ethics, it encourages the development of evaluation and re-evaluation of experience of interaction of school children with environment within the context of sustainability ideals.

Ecohumanist principle embodies general pedagogical principles of natural and cultural conformity, it is connected to the idea of co-evolution (harmony) of man and nature. This principle is based on the idea of unity between man and nature and it is aimed at the understanding by school children of the necessity to ensure co-creation of man and nature, responsibility for the conservation of social and natural environment.

Principle of consolidation and communication is connected to the development of co-evolutionary values in society as well as establishment of actor-actor relationships with nature. It encourages the development of ecologically aligned activities from the point of view of individual and social security.

Principle of orientation on real vital ecological problems implies the introduction of ecological problems in the education substance in the form of specific cross-disciplinary knowledge and new reality. This principle is based on the development of subjective experience when making decisions about ecological situations. It ensures interrelation of sensory, logical, theoretical and practical study of ecological problems.

Principle of uniqueness of a location expresses a regional study approach. A region territory is considered as a universal value for people who consider it to be their home land. Study of natural, cultural, social and economic uniqueness of a region, bonds with preceding and succeeding generations (popular traditions, art) become an important condition of environmental upbringing, allow to determine natural and cultural regional objects, expand spheres of activity for individuals and act as a basis for formation of environmental values. This principles implies a study of specific natural and cultural heritage, evolution of ecological situation in a region, spiritual, religion values as a basis of cultural traditions as well as historical and cultural, ethnocultural particularities of territory development.

Principle of global unity ("everything is connected to everything") develops environmental culture within the context of ideas of globalism, global mentality and such specific characteristics of such mentality as: perception of one-self as a part of the united humankind; perception of the modern world as a whole with all of its interrelations; orientation on humanistic values when solving ecological problems: predisposition to criticism, ability to learn lessons from past experience; reflexive interpretation of own experience within the context of human values; sense of justice, intolerance to war and violence.

Pedagogical level of co-evolutionary model of environmental consciousness development among school children is represented by the unity of target-oriented, substantive, procedural, performance evaluation components.

Scientific literature does not have a uniform understanding of ecological culture. Defined components of such culture do not always correspond to its specifics or can be interpreted much wider. In this connection and taking into account the described theoretical and methodological basic we have tried to define the main components of individual ecological culture which ensure sustainable development of the society (Gluzdova, Vinokurova and Nikolina, 2002; Kurova, (ed.), 1992).

Our research states that ecological culture includes interrelated coherent components:

- Cognitive component which ensures the development of ecological literacy (ecologically meaningful knowledge from perception to understanding, comprehension and use), ecologically-oriented mentality;

- Axiological component (ecological values, evaluation of attitude, emotion, "emotional resonance");

- Regulatory component (ethical and ecological imperative, ethical norms, rules, ecological traditions);

- Creative and pragmatist component which encourages the development of ecological mentality (experience of artistic, projective ecologically-oriented activity);

- Behavioral component (nature-friendly acts in respect of the nature) (Gluzdova, Vinokurova and Nikolina, 2002).

Thus, ecological culture of individual is a system the functioning of which is based upon harmonious interrelation of all spheres of individual mentality.

In current conditions a great importance is attributed to co-evolutionary orientations and values which together represent an axiological component and encourage a transition from nature conquest mentality orientations to coevolutionary ones (nature-friendly and culture conforming). One of the particularities of such new co-evolutionary mentality orientations is their creative side and transition from "I know", "I can", "I understand" to "I create for the sake of 
harmony between man and nature".

It is worth to underline that the defined components of ecological culture as a strategic purpose of ecological education for the sake of sustainability represent diagnostic instruments which allow to identify the criteria of its development (high, medium and low) on the basis of the above mentioned components.

Procedural component of the model is based upon the process of cultural acquisition by an individual of value and sense dominants of the environment. In this connection the mechanism of development of ecological culture comprises three stages. The first stage is a cultural and adaptation stage which is connected to emotions, emotional perception of ecological problems of the environment in the form of imaginative ideas, cultural symbols, signs, which ensure the identification and adaptation of an individual to social and natural environment. The second stage is a cultural and notional stage which consists in the fact that an individual comprehends and understands ecological knowledge and values. They become his/her personal heritage. The third stage is a cultural and artistic stage which is connected to the engagement of school children into creative activities aimed at the resolution of ecological problems of different scales. At this stage it is possible to have different types of creative activities: expressive, productive, innovative, induced.

Performance evaluation component implies the use of diagnostic objects, criteria of their development and applied methodology (Table 1, 2).

Table 1. Instruments of pedagogical diagnostics of the development of ecological culture components among school children.

\begin{tabular}{|c|l|l|l|}
\hline № & Indicators & Criteria & Methodology \\
\hline 1 & $\begin{array}{l}\text { Cognitive component of ecological } \\
\text { culture - ecological literacy }\end{array}$ & $\begin{array}{l}\text { Criterion of acquisition of ecological } \\
\text { knowledge (depth, generality, level of } \\
\text { comprehension) }\end{array}$ & $\begin{array}{l}\text { Methodology of evaluation of knowledge quality } \\
\text { (I.Ya. Lerner); methodology of evaluation of } \\
\text { environmental consciousness (Alekseev, 2014) }\end{array}$ \\
\hline 2 & $\begin{array}{l}\text { Axiological and regulatory component of } \\
\text { ecological culture - ecological values }\end{array}$ & $\begin{array}{l}\text { Criterion of axiological attitude to } \\
\text { nature: dominance, modality, intensity }\end{array}$ & $\begin{array}{l}\text { Methodology of determination of dominance of } \\
\text { ecological values, determination of modality, } \\
\text { intensity of attitudes (V.A. Yasvin, S.D. Deryabo } \\
\text { ("Aesop" methodology); typology of environmental } \\
\text { awareness (V.I. Panov) }\end{array}$ \\
\hline 3 & $\begin{array}{l}\text { Artistic and pragmatist component of } \\
\text { ecological culture - ecological mentality }\end{array}$ & Constructive and ecological activities & $\begin{array}{l}\text { Methodology of determination of ecological activity } \\
\text { /N.F.Vinokurova, A.K. Osnitskiy }\end{array}$ \\
\hline 4 & $\begin{array}{l}\text { Behavioral component of ecological } \\
\text { culture - ecologically-oriented activity }\end{array}$ & Criterion of preferred activity & $\begin{array}{l}\text { Associative methodology of preferred activity } \\
\text { "Alternative" }\end{array}$ \\
\hline
\end{tabular}

Table 2. Levels of development of ecological culture

\begin{tabular}{|c|l|l|}
\hline № & Level & Characteristics \\
\hline 1 & Low & $\begin{array}{l}\text { Ecological knowledge is represented at the level of facts, school children enumerate the main ecological problems; } \\
\text { consumer values prevail, objective and pragmatic type of relationships with environment is manifested; subjective } \\
\text { experience of culture and nature conforming activities within the context of sustainability is weakly expressed } \\
\text { (reproductive experience) }\end{array}$ \\
\hline 2 & Medium & $\begin{array}{l}\text { School children explain the essence of ecological problems and use this knowledge in familiar situations, they explain } \\
\text { cause-and-effect relationships which encourage the study and resolution of ecological problems; objective and non- } \\
\text { pragmatic type of relationships with environment is typical; low level of subjective experience of culture and nature } \\
\text { friendly activities within the context of sustainability (productive experience) }\end{array}$ \\
\hline 3 & High & $\begin{array}{l}\text { School children understand and apply knowledge about ecological problems in familiar and unfamiliar situations; co- } \\
\text { evolutionary values are predominant, subjective and non-pragmatic attitude to nature prevails. Artistic and subjective } \\
\text { experience of culture and nature friendly activities within the context of sustainability prevails (artistic experience) }\end{array}$ \\
\hline
\end{tabular}

2.3. The developed co-evolutionary model of ecological culture development among school children within the context of sustainable development ideas was tested in Nizhny Novgorod region (Russia) within the period of 2002-2012. 10 schools took part in the experiment ( 5 urban and 5 suburban schools). In total -335 school children of elementary, secondary and high school. The experiment was conducted on the basis of one class of each of ten schools after receipt of the expressed consent of teachers, school children and their parents to take part in the model's testing. The experiment was conducted upon the request of the Ministry of Education of Nizhny Novgorod region and the Committee of Environment and Nature Resources Protection of Nizhny Novgorod region.

2.3.1. Methods of the experiment's conduction were implemented taking into account the developed recommendations of the Center of Ecological Policy of Russia "Priorities of National Ecological Policy of Russia from the 
Federal Center to Regions" in the domain of the development of ecological culture (Yasvin, 2001).

In the course of the summative experiment the following methods of data collection were implemented: questioning of school children, parents, teachers of experimental classes, interviewing, monitoring, communication, methods of determination of environmental awareness typology (according to V.I. Panov).

Interviewing of pupils allowed to identify that they are not ready to give up on corresponding elements of comfort in the name of conservation of the natural environment diversity for the sake of future generations. Significant number of pupils (67\%) could be characterized by social apathy, they did not demonstrate any interest in the participation in environmental campaigns. This information is a distressing indicator of slow development of environmental awareness among pupils.

The analysis of questionnaires proposed to be filled in by parents testifies to the fact that families pay insufficient attention to a rational use of water and energy, rarely discuss environmental problems and their impact upon health, and quality of life of family members. Environmentally-oriented literation is practically absent from family reading domains.

The analysis of questionnaires filled in by teachers demonstrated that teachers are interested in the problems of environmental education and formation of environmental consciousness. Alongside with that, teachers have troubles when formulating theoretical and practical procedural issues of environmental culture formation based upon the innovational ideas of environmental development.

The use of the methodology of environmental awareness typology (according to V.I. Panov) allowed to draw the conclusion on the predominance among the interviewers of the anthropocentric type of environmental awareness rather than ecocentric one.

In order to increase the quality of evaluation teachers participating in the experiment were trained in order to better use the instruments of pedagogical diagnostics of ecological culture among school children.

The formative pedagogical experiment was conducted in natural conditions and implied the insertion of ecological elements in school subjects within the context of ecological culture and ideas of sustainability, as well as introduction of integrated classes with a cultural and ecological orientation together with insertion of ecological elements into school subjects (Kochurov, Vinokurova, Koposova and Smirnova, 2010; Vinokurova, Kamerilova, Nikolina et al., 2008; Vinokurova, Kamerilova, and Nikolina, 2007; Vinokurova, 2012; Vinokurova and Trushin, 2001).

In order to develop ecological culture special program tools were created which allowed the school children to get acquainted with the culture of a home land, country and the world, to learn about ecological conditions, natural and cultural heritage.

In this connection a modular program approach was used which comprised the development of separate ecological modules and an integral program of elective class "Ecological culture". A total sum of ecological modules for various levels of education (primary, secondary and high school) were united under the general individual-oriented topic - "I in various spheres of ecological culture".

The module for elementary school was prepared taking into account the ideas and methods of American teachers and ecologists: Maura O'Connor, author of the ecological upbringing course "Living Lightly" and Joseph Cornell - author of environmental educational program which makes use of outdoor activities (Cornell, 1999; O'Connor, 1993). The module for elementary schools bore the name of "My Friend Nature". The module implied the use of games, sightseeing tours, tasks oriented at the development of fantasy and artistic abilities.

Thematic unity of modular program approach in the secondary school (grades 5-9) consisted in the unification of content around three ecological modules "Ecology of my Home", "Region where I Live", "My City". The main ideas of axiological components of these modules are: a pupil - as a subject of ecological culture, its acting part, development of ecological culture values by means of insertion into a multidimensional educational environment of various scales; enriching of modules' contents with co-evolutionary senses and values.

Particularity of the developed modules consists in the understanding: of the ecological culture as the basis for the sustainable society development; studying of module contents on the basis of real ecological problems of global, regional and local scale; methods of education based on co-evolutionary ideas of cooperation, dialogue, variation, productivity of various activities.

For pupils of $10^{\text {th }}$ and $11^{\text {th }}$ grades the module "To think globally - to act locally" was developed. The content of the module is aimed at the development of the global ecological mentality. Its axiological component reflected a new mentality paradigm consisting of interrelations between individuals, humanity and nature of the Earth which imply a transition from the conquest ideology to a harmonious coexistence.

The above mentioned modules were inserted in the existing educational programs or were used separately in the form of module courses.

In the course of the module development we were governed by the following definition of an ecological module. By 
a term of the ecological module we define a logically completed block of ecological information which requires for its comprehension and study engagement of pupils into cognitive, communicative, axiological, design and practical activities (Gluzdova, Vinokurova and Nikolina, 2002). In this connection within the framework of the defined modules it was intended to use abstracts of various literature, to perform ecological research, sightseeing events, ecological projects, games, discussions, seminars, cultural and ecological practical classes in a social and natural environment.

In the $10^{\text {th }}$ and $11^{\text {th }}$ grades the module was also accompanied by the study of the "Ecological culture" course. It implied the study of history of relationships of man and nature; particularities of the development of ecological culture within the context of ideas of sustainable development; types of ecological and creative activities in the environment. The class structure also implied the synthesis of two types of experience: substantive and objective and individual. In this connection the educational program made use of educational technologies which ensure a transition of objective knowledge into individual values: technology of training tasks, games, projects, workshops, volunteer activities. They update and develop among pupils the feeling of self-fulfillment, reflexion, participation, consolidation in the course of resolution of ecological problems.

\section{Results and Discussion}

Gathered experimental data allow to make a conclusion that the majority of the experiment participants developed aspects of ecological culture. High and medium level of constructive ecological activity was shown by $72 \%$ of pupils participating in the experiment. In all experimental classes as compared to the classes where the experiment was not conducted higher indicators of depth, generality and understanding of ecological knowledge were revealed. The results of the diagnostics testify to the fact that $21 \%$ of pupils of experimental classes exhibit subjective and non-pragmatical attitude to nature. Meanwhile in the classes which did not partake in the experiment more that $60 \%$ of pupils express only objective and pragmatical attitude. Statistical analysis of the results received with the use of "Naturofil" methodology showed that all parameters of attitude to nature (emotive positive perception of nature, desire to enter into a personal contact with the world of nature, nature-friendly activities, knowledge of nature) of the pupils of the experimental classes significantly exceed the indicators of those classes which did not participate in the experiment. Significant differences were revealed between pupils of urban and suburban schools in the domain of constructive and ecological activities. Suburban school pupils have a significantly higher level of emotional positive perception of nature than urban school pupils.

Received results about the level of development of subjective experience of ecological activities among pupils testify to the fact that $63 \%$ of high school pupils desire and are ready to practically participate in the resolution and prevention of ecological problems, amelioration of city and village territories.

Statistical analysis of the results received with the use of "Aesop" and "Alternative" methodology showed that there is a concordance between the attitude and the behavior of teenage pupils. From the point of view of axiological attitude nature was perceived by pupils from various positions as the universal value. Behavior of the majority of pupils (72\%) was oriented towards learning, aesthetic evaluation, rational use of natural resources.

In this connection it is important to underline that the recorded phenomenon presented in the research of ecological education (Yasvin, 2001), connected to the detection of pragmatic attitude of pupils to nature was successfully overcome in the course of the research.

In general after the unification of the gathered information it was found that a low level of development of ecological culture was manifested by $7 \%$ of pupils, $72 \%$ of pupils had a medium level of culture and $21 \%$ - a high level. Gathered results of the research allow to state the effectiveness and efficiency of the experimental method. The authors of the article - N.F. Vinokurova, V.V. Nikolina were awarded with the prize of the city of Nizhny Novgorod in the domain of environment for their work in the sphere of environmental education.

Quantitative and qualitative results of the experiment, duration of its performance within more than 10 years, possibility to monitor the process of development of ecological culture of pupils of urban and suburban schools allow to state that the co-evolutionary model of development of individual ecological culture of pupils of urban and suburban schools is efficient, capable of being copied, and is accompanied by training and methodological materials. It significantly increases the possibility of its further use.

There are some unresolved problems of development of ecological culture of pupils such as a research connected to the study of possible social partnership in the course development of ecological culture. A more narrow pedagogical problem connected to the identification of functions of various subjects in the course of development of ecological culture for the sake of sustainability within the uniform educational environment still needs to be studied. The problem of a study of possibilities of use of international standards of ecological education quality becomes topical today. 


\section{Conclusions}

Scientific novelty and theoretical importance of the research consists in the following:

- scientific justification and explanation of co-evolutionary model of development of ecological culture of pupils at three levels: philosophical and methodological, theoretical and methodological, pedagogical, which corresponds to the hierarchy of performance of pedagogical researches;

- a set of approaches and a system of principles which constitute the methodological basis for the development of ecological culture of pupils within the context of ideas of sustainability were defined, justified and explained;

- the main components of ecological culture were explained: target-oriented which justifies the essence of the ecological culture as a strategic target of education in the XXI century; substantive which reflects the structure of ecological culture; procedural which is based upon the process of cultural acquisition by an individual of the social and cultural environment; performance evaluation component which is represented by the instruments of pedagogical diagnostics, which includes indicators, criteria and methods of evaluation of the degree of development of ecological culture among pupils within the context of ideas of sustainability;

- training ecological modules which reflect the continuity and consistency of the development of ecological culture of pupils were developed.

Practical importance of the research consists in the following:

- programs and educational materials of author's integrated ecological courses were created such as: "Natural resources management" (Vinokurova, Kamerilova, and Nikolina, 2007), "Global ecology" (Vinokurova and Trushin, 2001), "Forest and man" (Vinokurova, Kamerilova, Nikolina et al., 2008), "Modern ecological problems", "Environmental geo-ecology" (Kochurov, Vinokurova, Koposova and Smirnova, 2010), published in the central publishing houses of Russia - "Prosveshenie", "Drofa", "Ventana- Graf";

- the following ecological modules were developed and introduced in the educational program of schools: "My friend nature", "I in various spheres of ecological culture", "To think globally - to act locally".

Various tasks and aspects of a study of the problem of development of ecological culture of pupils were encouraged by the rewards received at the regional and federal levels. Authors would like to express their gratitude to teachers, pedagogical environment who participated in the performance and discussion of results of the experiment. Authors would also like to express their gratitude to the publishing houses "Prosveshenie", "Drofa" and "Ventana-Graf" for the possibility to publish training and methodological materials ensuring methodological accompanying of the coevolutionary model of development of ecological culture of pupils.

\section{References}

Alekseev S.V. (2014) Continuous environmental education of a teacher - indispensable factor of efficient development of environmental culture among young people. Environmental education, $3: 10-13$.

Cornell, J. (1999) Sharing nature with children: the classic parents' and teachers' nature awareness guidebook. Translated from English. Vladivostok: Isar - Far East

Deryabo, S.D. (1996) Ecological pedagogy and psychology. Rostov-on-Don: Feliks.

Doronina O.D., Kuznetsov O.L., Rokhianin Yu.A. (2005) UN Strategy for sustainable development within the context of globalization. Revised by N.F. Izmerova. Moscow: Russian Academy of Natural Sciences, $247 \mathrm{p}$.

Feldshtein, D.I. (2012) Psychological science as a resource for the development of a modern society. Pedagogy, 1: 3-16.

Gluzdova, V.A., Vinokurova, N.F. and Nikolina, V.V. (2002). Concept of ecological education of pupils of Nizhny Novgorod within the context of ideas of sustainability. Nizhny Novgorod: VVASS

Kochurov, B.I., Vinokurova, N.F., Koposova, N.N. and Smirnova, V.M. (2010) Environmental geoecology. Moscow: Ventana-Graf.

Krylova, N.B. (2000) Educational culturology. Moscow.

Kurova, I.E. (ed.) (1992) Regional program of continuous ecological education of Nizhny Novgorod region. Nizhny Novgorod.

Lerner, I. Ya. (1981) Didactic foundations of educational methods. Moscow: Pedagogy.

Nikolina V.V. , Vinokurova, N.F., Kamerilova, G.S., Kartavykh, M.A. and Demidova N.N. (2011) Nizhny Novgorod scientific school of continuous ecological education. Higher education in Russia, 7: 46-52.

O'Connor, M. (1993) Living lightly. Environmental education guidebook for students. Part 1. (6-9 years) Translated from English.

Osnitskiy, A.K. (1996) Self-regulation of pupils' activities and development of individual activity. Moscow: Pedagogy.

Ponomareva, I.N. \& Solomin V.P. (2008) Ecological education in Russian school: History. Theory. Methodology: Educational Material. edited by V.P. Solomin. Saint Petersburg: Publishing house of RSPU named after A.I. Herzen, 415 p.

Our Common Future (1989): Report of the World Commission on Environment and Development (WCED): Translated from English. Revised and noted by S.A. Evteeva and R.A. Pereleta, Moscow: Progress, $376 \mathrm{p}$.

Science and education for the sake of sustainability (2006). Collective monography. Moscow 2006. 
Suravegina, I.T. (1986) Theory and practice of development of responsible attitude to nature in the course of biology studies: synopsis of thesis of the doctor of pedagogical sciences. Moscow

Vinokurova, N.F. (2012) Geoecological education: continuity and innovations. Geography in school, 5, 21-26.

Vinokurova, N.F., Kamerilova, G.S. and Nikolina V.V. (2007) Natural resources management: text book for $10^{\text {th }}$ and $11^{\text {th }}$ classes. Moscow: Drofa.

Vinokurova, N.F., Kamerilova, G.S., Nikolina V.V. et al. (2008). Forest and man: text book for 9th class. Moscow: Drofa.

Vinokurova, N.F., Trushin, V.V. (2001) Global ecology: text book for $10^{\text {th }}-11^{\text {th }}$ classes. Moscow: Prosveshenie.

World bank (2014) Report on the world development «Risks and possibilities: management of risks for the sake of development»

Yasvin, V.A. (2000) History and psychology of development of ecological culture: Is it convenient to sit in the top of the pyramid. Moscow: Science.

Yasvin, V.A. (2000) Psychology of attitude to nature. Moscow: Sense, 456 pages.

Yasvin, V.A. (2001) Regional ecological policy of development of ecological culture. Moscow: CEPR. 66 p.

Zakhlebny, A.N., Dzyatovskay, E.N. (2010) Models of ecological education in new school. Pedagogy, 9, 38-44.

Zverev, I.D. (1980) Ecology in school education. Moscow: Znanye 